\title{
Formação in vitro de raízes em canafístula: $o$ efeito de diferentes meios de cultivo
}

\author{
In vitro rhizogenesis in Peltophorum dubium the effect of different culture media
}

\section{RESUMO}

A canafistula [Peltophorum dubium (Spreng.) Taub.] é uma espécie florestal nativa do Brasil, dotada de características silviculturais promissoras para fins de (re)florestamento. No entanto, a produção de mudas de alta qualidade por meio da micropropagação é limitada pela reduzida formação de raizes. Em virtude disso, o presente estudo teve como objetivo avaliar o efeito de substratos alternativos ao ágar e do periodo de cultivo na formação in vitro de raízes de canafistula. Para tanto, foram testados, aos 30 e 60 dias de cultivo in vitro, meios de cultivo compostos por combinações dos substratos vermiculita (V), Plantmax $^{\circledR}(P)$ ou areia fina $(A F)$ ao meio nutritivo $M S$, contendo $10 \mu M$ de ácido 3-indol butírico (AIB), acrescido ou não de ágar (A). Obteve-se elevada sobrevivência das brotações, tanto aos 30 (92,3\%) quanto aos 60 (82,6\%) dias de cultivo. Em relação aos meios de cultivo, a maioria deles proporcionou uma elevada sobrevivência (91,1 a 100,0\%) das brotações; constituíram exceções àqueles que continham $(P)$. Intensa formação calogênica foi observada apenas após 60 dias de cultivo, na testemunha, que incluiu MS e (A), e naqueles outros dois tratamentos contendo (V). O melhor resultado de formação de raizes, tanto quantitativamente (36,78\%) como pela qualidade das raizes, foi obtido no tratamento que incluiu $(V)$ e (A), além de MS, aos 60 dias de cultivo. Com a utilização de (V) no meio de cultivo, há intensa formação de calos, aos 60 dias de cultivo, porém, também há maior formação de raizes e melhoria na qualidade do sistema radicular, quando este substrato é combinado ao meio nutritivo MS.

Palavras-chave: cultura de tecidos, espécie florestal, vermiculita, areia fina, Plantmax ${ }^{\circledR}$ ágar.

\section{ABSTRACT}

Peltophorum dubium (Spreng.) Taub is a forest species native to Brazil endowed with promising forestry features for the purposes of afforestation. However, production of seedlings of high quality through micropropagation is limited by the reduced root formation. As a result, the present study aimed to evaluate the effect of alternative substrates to the agar and the culture period in the in vitro formation of roots. It was tested at 30 and 60 days of in vitro culture, culture media composed of combinations of substrates vermiculite (V), Plantmax ${ }^{\mathbb{B}}(P)$ or fine sand (FS) to MS nutritive medium containing $10 \mu \mathrm{M}$ of 3-indole butyric acid (IBA), with agar or not (A). Was obtained a high survival rate of shoots both the $30(92.3 \%)$ and 60 (82.6\%) days of culture. Most culture media yielded high survival (91.1 to 100\%) but those containing $(P)$ constituted exceptions. Intense calli formation was observed only after 60 days of culture, in the control, which contained MS and $(A)$, and in those other two treatments containing $(V)$. The best result of root formation as much quantitatively (36.78\%) as for the quality were obtained on treatment that included (V) and (A), in addition to MS at 60 days of culture. With the use of $(V)$ in the culture medium there is intense calli formation after 60 days of culture but also there is higher root formation and improvement in the quality when this substrate is combined with nutritive medium $M S$.

Key words: tissue culture, forest species, vermiculite, fine sand, Plantmax ${ }^{\mathbb{B}}$, agar.

\section{INTRODUÇÃO}

O setor florestal brasileiro vem crescendo consideravelmente em virtude das condições edafoclimáticas favoráveis, aliadas a grandes investimentos de capital e utilização de tecnologias avançadas na silvicultura. Esse crescimento se dá, principalmente, com a utilização de espécies exóticas de rápido crescimento, necessárias para atender a demanda por produtos de origem florestal. No entanto, o Brasil dispõe de espécies nativas

'Departamento de Fitotecnia, Universidade Federal de Santa Maria (UFSM), 97105-900, Santa Maria, RS, Brasil. E-mail: liarsr@ufsm.br. Autor para correspondência.

"Programa de Pós-graduação em Engenharia Florestal, UFSM, Santa Maria, RS, Brasil. 
potenciais para utilização em larga escala, mas que carecem, ainda, de estudos direcionados à resolução de problemas relacionados à obtenção de mudas de elevada qualidade genética, fisiológica e sanitária para a produção florestal.

\section{A canafístula [Peltophorum dubium} (Spreng.) Taub.], pertencente à família Fabaceae, ocorre naturalmente no Rio Grande do Sul e em outros estados brasileiros, destacando-se entre as espécies florestais nativas pelo rápido crescimento. Além disso, é muito rústica e heliófila, sendo adequada para reflorestamentos mistos de áreas degradadas e dotada de potencial para utilização em sistemas produtivos e em escala comercial. Sua madeira possui moderada resistência ao apodrecimento, sendo bastante usada na construção civil (DONADIO \& DEMATTÊ, 2000; BASSAN et al., 2006). Entretanto, existem escassas informações referentes às técnicas de propagação vegetativa visando à obtenção de mudas de qualidade dessa espécie. Nesse sentido, técnicas de cultura de tecidos podem viabilizar a obtenção de matériasprimas de maior qualidade.

Estudos anteriores realizados com canafístula limitaram-se às fases de estabelecimento e multiplicação in vitro objetivando comparar os meios nutritivos MS e WPM e segmentos caulinares apicais e nodais (BASSAN et al., 2006), e, depois, avaliar a melhor concentração do meio nutritivo MS (FLÔRES et al., 2011) com vistas à multiplicação da espécie. Os resultados obtidos indicaram que a espécie tem potencial para a micropropagação, no entanto, não incluíram a formação in vitro de raízes, principal motivação para a realização do presente estudo.

A utilização de diferentes classes de fitorreguladores e alterações na composição de outros componentes dos meios nutritivos podem auxiliar na obtenção de resultados mais promissores, especialmente na formação de raízes, que é uma das fases limitantes do cultivo in vitro de espécies florestais. Nesse sentido, alternativas ao ágar, componente frequentemente utilizado na cultura de tecidos para gelificar os meios de indução à rizogênese, vêm sendo pesquisadas em diversos trabalhos, uma vez que tem sido observado que o sistema radicular, formado em brotações cultivadas na presença desse agente, é quebradiço e desprovido de pelos radiculares (JAY-ALLEMAND et al., 1992; VIAGANÓ et al., 2007). Em consequência, as raízes formadas em meios contendo ágar, em geral, são pouco eficientes na absorção de água e nutrientes durante a aclimatização, resultando em baixa sobrevivência das plantas (HOFFMANN et al., 2001). Adicionalmente, o ágar é a substância de maior custo dentre os componentes do meio nutritivo (VIAGANÓ et al., 2007). Vermiculita, perlita ou espumas de poliuretano embebidas de meio nutritivo líquido podem constituir alternativas mais baratas e produzir melhores resultados do que o ágar nos meios de indução à rizogênese (FARIA et al., 2006; JAY-ALLEMAND et al., 1992; HOFFMANN et al., 2001; VIEIRA et al., 2007). Considerado o exposto, o presente estudo teve como objetivo avaliar o efeito de substratos alternativos ao ágar e do período de cultivo na formação in vitro de raízes de canafístula.

\section{MATERIAL E MÉTODOS}

As sementes utilizadas no presente estudo foram coletadas e armazenadas pela Fundação Estadual de Pesquisa Agropecuária - Fepagro/ Florestas em Santa Maria, RS, e são provenientes da produção de 2005. Após sua aquisição, permaneceram armazenadas em frascos de vidro contendo sílica gel e acondicionadas sob temperatura de $8-10^{\circ} \mathrm{C}$, em refrigerador, até o seu emprego nos ensaios descritos a seguir, que foram realizados em 2009 e 2010.

Inicialmente, as sementes foram submetidas à superação de dormência por meio de escarificação mecânica com lixa no 100 na região oposta ao embrião. Em seguida, em câmara de fluxo laminar, foram desinfestadas superficialmente em solução de etanol a $70 \%$ (v/v) por 30s e, após, em solução de hipoclorito de sódio $(\mathrm{NaOCl})$ a $2 \%(\mathrm{v} / \mathrm{v})$ por $15 \mathrm{~min}$, passando, então, por triplo enxágue em água destilada e autoclavada.

Posteriormente, visando a promover a germinação in vitro, foram inoculadas, sob câmara de fluxo laminar, três sementes por frasco de vidro com capacidade para $150 \mathrm{~mL}$, contendo $30 \mathrm{~mL}$ de meio ágar-água a $0,7 \%(\mathrm{p} / \mathrm{v})$, previamente autoclavados por um período de $40 \mathrm{~min}$ a $120^{\circ} \mathrm{C}$ e $1 \mathrm{~atm}$. Decorridos 15 dias de cultivo, foram isolados, das plântulas germinadas in vitro, epicótilos com, aproximadamente, 8 a $10 \mathrm{~mm}$ de comprimento, os quais foram inoculados em frascos de vidro com capacidade para $150 \mathrm{~mL}$, contendo $30 \mathrm{~mL}$ de meio nutritivo MS (MURASHIGE \& SKOOG, 1962) acrescido de $30 \mathrm{~g} \mathrm{~L}^{-1}$ de sacarose, $100 \mathrm{mg} \mathrm{L}^{-1}$ de mioinositol, $7 \mathrm{~g} \mathrm{~L}^{-1}$ de ágar e $1 \mathrm{~g} \mathrm{~L}^{-1}$ de carvão ativado. $\mathrm{O}$ $\mathrm{pH}$ foi ajustado para 5,8 antes da inclusão do ágar e, posteriormente, o meio nutritivo foi autoclavado por $15 \mathrm{~min}$ a $120^{\circ} \mathrm{C}$ e a $1 \mathrm{~atm}$. Em ambas a fases, os frascos foram vedados e mantidos em sala de cultivo, sob temperatura de $25 \pm 3^{\circ} \mathrm{C}$, fotoperíodo de $16 \mathrm{~h}$ e intensidade luminosa de $20 \mu \mathrm{mol} \mathrm{m} \mathrm{m}^{-2} \mathrm{~s}^{-1}$ fornecida por lâmpadas fluorescentes brancas frias tipo luz do dia. 
$\mathrm{Na}$ sequência, as brotações obtidas, contendo de 1 a 3 pares de folhas, foram utilizadas como explantes no ensaio de rizogênese, em que foi adotado o delineamento experimental inteiramente casualizado, em arranjo bifatorial $7 \times 2$. O fator A referiuse aos diferentes meios de cultivo (Tabela 1), formados pela combinação de volumes de meio nutritivo MS (acrescido de $30 \mathrm{~g} \mathrm{~L}^{-1}$ de sacarose, $100 \mathrm{mg} \mathrm{L}^{-1}$ de mioinositol e $10 \mu \mathrm{M}$ de ácido 3-indol butírico - AIB) com volumes de diferentes substratos, acrescidos ou não de ágar. $\mathrm{O}$ fator $\mathrm{B}$ correspondeu ao período de avaliação (após 30 e após 60 dias de cultivo in vitro). Foram utilizadas 10 repetições, cada uma composta por um frasco de vidro com capacidade para $150 \mathrm{~mL}$, contendo a combinação respectiva de meio nutritivo MS e substrato (vermiculita, Plantmax $^{\circledR}$ ou areia fina), com ou sem ágar, e três brotações. $\mathrm{O}$ pH do meio nutritivo foi ajustado para 5,8 antes da inclusão de ágar (para os tratamentos que o continham), vermiculita, Plantmax ${ }^{\circledR}$ ou areia fina; e, posteriormente, os meios de cultivo foram autoclavados a $120^{\circ} \mathrm{C}$ e $1 \mathrm{~atm}$ de pressão por $15 \mathrm{~min}$. Os frascos foram vedados e mantidos em sala de cultivo, conforme descrito anteriormente.

Após a primeira avaliação, aos 30 dias, as brotações foram mantidas por um período adicional de 30 dias em meio de cultivo fresco de constituição idêntica àquela usada no primeiro período. $\mathrm{Na}$ transferência, aquelas brotações que apresentaram intensa formação de calos na base tiveram estas estruturas removidas, com o intuito de não prejudicar a formação in vitro de raízes. As variáveis analisadas aos 30 e aos 60 dias foram: sobrevivência das brotações, brotações que formaram calo na base e formação in vitro de raízes, todas expressas em porcentagem.

Após testar a normalidade dos erros por meio do teste de Kolmogorov-Smirnov e a homogeneidade de variâncias pelo teste de Bartlett, as médias, sempre que necessário, foram transformadas pela função $\sqrt{x+0,5}$, sendo x o valor observado. Os resultados apresentados são as médias originais obtidas. Foram realizadas análises de variância e, quando o valor de $\mathrm{F}$ foi significativo, utilizou-se, para a comparação das médias, o teste de Scott-Knott ao nível de 5\% de probabilidade de erro. Utilizaram-se os programas estatísticos SISVAR 4.0 (FERREIRA, 2000) e BioEstat 5.0 (AYRES et al., 2007). A precisão dos ensaios foi estimada pela acurácia seletiva (AS), calculada por $\sqrt{1-(1 / F c)}$, a qual corresponde à correlação linear entre os valores genotípicos e fenotípicos.

\section{RESULTADOS, DISCUSSÃO E CONCLUSÃO}

A precisão do ensaio objeto de relato no presente trabalho foi satisfatória, obtendo-se estimativas de AS de 0,81 a 0,99 , o que correspondeu a acurácias alta e muito altas, conforme classificação de RESENDE E DUARTE (2007). Os valores observados de AS permitem, portanto, depositar uma elevada confiança nas avaliações efetuadas.

Para a sobrevivência, houve efeito significativo apenas para os fatores principais: período de avaliação $(\mathrm{P}=0,0055 ; \mathrm{AS}=0,93)$ e meio de cultivo $(\mathrm{P}=0,000 ; \mathrm{AS}=0,95)$. Quanto ao período de avaliação, foi observada maior sobrevivência das brotações $(92,3 \%)$ após 30 dias de cultivo in vitro; após 60 dias, a sobrevivência foi de $82,6 \%$, provavelmente, decorrente do período prolongado de cultivo in vitro, uma vez que algumas brotações já apresentavam sinais de senescência. Isso está de acordo com resultados preliminares (dados não publicados) obtidos, que revelaram que o ciclo in vitro de canafístula, nas mesmas condições testadas no presente estudo, é de cinco semanas, após o que começam a ocorrer amarelecimento e abscisão de folhas.

Os meios de cultivo que apresentaram os piores resultados de sobrevivência foram aqueles que continham Plantmax ${ }^{\circledR}$ na sua composição, quer seja combinado apenas ao meio nutritivo MS $(\mathrm{M}+\mathrm{P})$

Tabela 1 - Codificação e composição dos meios de cultivo testados na rizogênese de brotações de canafístula [Peltophorum dubium (Spreng.) Taub.].

\begin{tabular}{|c|c|}
\hline Codificação & 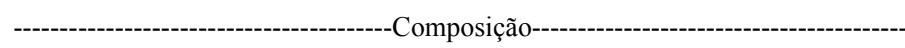 \\
\hline $\mathrm{M}+\mathrm{A}$ (testemunha) & $30 \mathrm{~mL}$ de $\mathrm{MS}+7 \mathrm{~g} \mathrm{~L}^{-1}$ de ágar \\
\hline $\mathrm{M}+\mathrm{V}$ & $25 \mathrm{~mL}$ de $\mathrm{MS}+30 \mathrm{~cm}^{3}$ de vermiculita granulometria fina \\
\hline $\mathrm{M}+\mathrm{V}+\mathrm{A}$ & $25 \mathrm{~mL}$ de $\mathrm{MS}+30 \mathrm{~cm}^{3}$ de vermiculita granulometria fina $+7 \mathrm{~g} \mathrm{~L}^{-1}$ de ágar \\
\hline $\mathrm{M}+\mathrm{P}$ & $15 \mathrm{~mL}$ de $\mathrm{MS}+30 \mathrm{~cm}^{3}$ de Plantmax ${ }^{\circledR}$ \\
\hline $\mathrm{M}+\mathrm{P}+\mathrm{A}$ & $15 \mathrm{~mL}$ de $\mathrm{MS}+30 \mathrm{~cm}^{3}$ de Plantmax ${ }^{\circledR}+7 \mathrm{~g} \mathrm{~L}^{-1}$ de ágar \\
\hline $\mathrm{M}+\mathrm{AF}$ & $10 \mathrm{~mL}$ de $\mathrm{MS}+30 \mathrm{~cm}^{3}$ de areia fina \\
\hline $\mathrm{M}+\mathrm{AF}+\mathrm{A}$ & $15 \mathrm{~mL}$ de $\mathrm{MS}+30 \mathrm{~cm}^{3}$ de areia fina $+7 \mathrm{~g} \mathrm{~L}^{-1}$ de ágar \\
\hline
\end{tabular}


quer seja ao $\mathrm{MS}$ e ao ágar $(\mathrm{M}+\mathrm{P}+\mathrm{A})$, os quais diferiram entre si (55,8 e 79,4 respectivamente). As demais composições de meio de cultivo (Figura 1A) não diferiram entre si e apresentaram uma elevada sobrevivência $(91,1$ a $100,0 \%)$ das brotações. Provavelmente, os menores índices de sobrevivência observados nos tratamentos que continham Plantmax ${ }^{\circledR}$ se devem ao volume de meio nutritivo que foi utilizado para umedecer o substrato. Apesar de ter sido menor $(15 \mathrm{~mL})$ do que o volume utilizado na testemunha $(30 \mathrm{~mL})$ e nos tratamentos com vermiculita $(25 \mathrm{~mL})$, pôde-se perceber um certo encharcamento do substrato, o que acabou causando necrose na base das brotações (Figura 1B) e, por consequência, prejudicou a sobrevivência das brotações (Figura 1C). Igualmente, é possível que o volume de meio nutritivo utilizado também tenha afetado a disponibilidade de nutrientes para as brotações. No entanto, nos meios de cultivo que incluíram areia, o volume de meio nutritivo utilizado foi igual $(15 \mathrm{~mL}$, no tratamento com ágar), ou menor $(10 \mathrm{~mL})$ e, apesar disso, os índices de sobrevivência observados foram satisfatórios, não havendo indícios de deficiência nutricional nas brotações. Diferentemente, para macieira (Malus domestica Borkh), a maior sobrevivência de plantas enraizadas foi em meio gelificado com ágar e em Plantmax ${ }^{\circledR}$ (HOFFMANN et al., 2001).

Para as brotações que formaram calo na base, foi observada interação entre os fatores principais meio de cultivo e período de avaliação $(\mathrm{P}=0,000 ; \mathrm{AS}=0,99)$, indicando que os dois fatores atuam conjuntamente na calogênese (Tabela 2). Nos primeiros 30 dias de cultivo, não foi observada formação de calos no tratamento testemunha $(\mathrm{M}+\mathrm{A})$ e nem naqueles que continham vermiculita como substrato, e, nos demais tratamentos, observaramse reduzidas porcentagens de calogênese. Não foi,

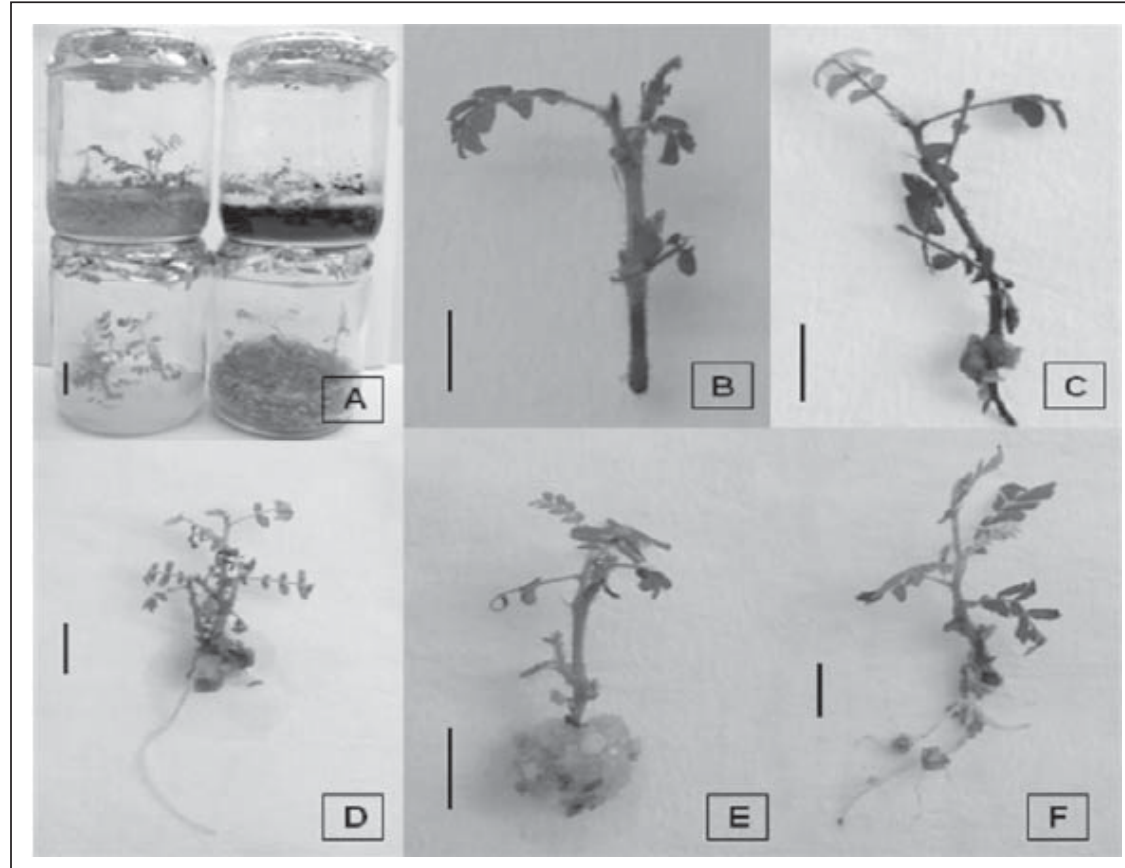

Figura 1 - Aspecto das brotações de canafístula [Peltophorum dubium (Spreng.) Taub.] no processo de formação in vitro de raízes em diferentes meios de cultivo. Em A), brotações cultivadas in vitro em meio de cultivo contendo areia, Plantmax ${ }^{\circledR}$, ágar ou vermiculita, combinados com meio MS, acrescido de $10 \mu \mathrm{M}$ de AIB; em B), observa-se necrose que ocorreu na base das brotações cultivadas em meio de cultivo contendo Plantmax ${ }^{\circledR}$, combinado com meio MS, acrescido de $10 \mu \mathrm{M}$ de AIB, após 30 dias de cultivo; e, em C), após 60 dias de cultivo no mesmo meio; em D), planta com raiz formada em meio de cultivo contendo meio nutritivo MS, acrescido de $10 \mu \mathrm{M}$ de AIB e $7 \mathrm{~g} \mathrm{~L}-1$ de ágar (testemunha); em E), intensa formação de calos observada na base das brotações em meio de cultivo contendo vermiculita, combinada com meio MS acrescido de $10 \mu \mathrm{M}$ de AIB; e em F), planta com raiz formada em meio de cultivo contendo vermiculita como substrato, combinada com meio nutritivo MS, acrescido de $10 \mu \mathrm{M}$ de $\mathrm{AIB}$ e $7 \mathrm{~g} \mathrm{~L}^{-1}$ de ágar. Barra $=1 \mathrm{~cm}$. Santa Maria, RS, UFSM, 2010. 
Tabela 2 - Formação de calos (\%) na base de brotações e formação in vitro de raízes (\%) em brotações de canafístula [Peltophorum dubium (Spreng.) Taub.], após 30 e 60 dias de cultivo in vitro em diferentes substratos, combinados com meio nutritivo MS, acrescido de10 $\mu \mathrm{M}$ de ácido 3-indol butírico (AIB). Santa Maria, RS, UFSM, 2010.

\begin{tabular}{|c|c|c|c|c|c|c|}
\hline \multirow{2}{*}{ Meio de Cultivo } & \multicolumn{3}{|c|}{ - } & \multicolumn{3}{|c|}{ 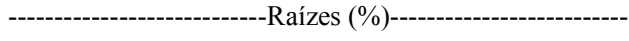 } \\
\hline & 30 dias & 60 dias & Média $(\%)$ & 30 dias & 60 dias & Média (\%) \\
\hline $\mathrm{M}+\mathrm{A}^{*}$ & $0,00 \mathrm{aA}^{* *}$ & $96,22 \mathrm{bB}$ & 45,58 & $0,00 \mathrm{aB}$ & $3,67 \mathrm{bB}$ & 1,74 \\
\hline $\mathrm{M}+\mathrm{V}$ & $0,00 \mathrm{aA}$ & $96,22 \mathrm{bB}$ & 45,58 & $0,00 \mathrm{aB}$ & $7,33 \mathrm{bB}$ & 3,47 \\
\hline$M+V+A$ & $0,00 \mathrm{aA}$ & $96,22 \mathrm{bB}$ & 45,58 & $3,30 \mathrm{aB}$ & $36,78 \mathrm{aA}$ & 19,16 \\
\hline $\mathrm{M}+\mathrm{P}$ & $3,30 \mathrm{aA}$ & $0,00 \mathrm{aA}$ & 1,74 & $3,30 \mathrm{aB}$ & $3,67 \mathrm{bB}$ & 3,47 \\
\hline $\mathrm{M}+\mathrm{P}+\mathrm{A}$ & $3,30 \mathrm{aA}$ & $0,00 \mathrm{aA}$ & 1,83 & $0,00 \mathrm{aB}$ & $16,50 \mathrm{bA}$ & 7,33 \\
\hline $\mathrm{M}+\mathrm{AF}$ & $6,60 \mathrm{aA}$ & $0,00 \mathrm{aA}$ & 3,30 & $3,30 \mathrm{aB}$ & $6,60 \mathrm{bB}$ & 4,95 \\
\hline $\mathrm{M}+\mathrm{AF}+\mathrm{A}$ & $3,30 \mathrm{aA}$ & $0,00 \mathrm{aA}$ & 1,65 & $0,00 \mathrm{aB}$ & $9,90 \mathrm{bB}$ & 4,95 \\
\hline Média (\%) & 2,36 & 40,59 & 20,62 & 1,41 & 11,87 & 6,41 \\
\hline $\mathrm{AS}^{* * *}$ & 0,99 & & & 0,81 & & \\
\hline
\end{tabular}

$* \mathrm{M}+\mathrm{A}=30 \mathrm{~mL}$ de meio nutritivo $+7 \mathrm{~g} \mathrm{~L}^{-1}$ de ágar; $\mathrm{M}+\mathrm{V}=25 \mathrm{~mL}$ de meio nutritivo $+30 \mathrm{~cm}^{3}$ de vermiculita granulometria fina; $\mathrm{M}+\mathrm{V}+\mathrm{A}=$ $25 \mathrm{~mL}$ de meio nutritivo $+30 \mathrm{~cm}^{3}$ de vermiculita granulometria fina $+7 \mathrm{~g} \mathrm{~L}^{-1}$ de ágar; $\mathrm{M}+\mathrm{P}=15 \mathrm{~mL}$ de meio nutritivo $+30 \mathrm{~cm}^{3}$ de $\mathrm{Plantmax}$; $\mathrm{M}+\mathrm{P}+\mathrm{A}=15 \mathrm{~mL}$ de meio nutritivo $+30 \mathrm{~cm}^{3}$ de Plantmax ${ }^{\circledR}+7 \mathrm{~g} \mathrm{~L}^{-1}$ de ágar; $\mathrm{M}+\mathrm{AF}=10 \mathrm{~mL}$ de meio nutritivo $+30 \mathrm{~cm}^{3}$ de areia fina $\mathrm{e}$ $\mathrm{M}+\mathrm{AF}+\mathrm{A}=15 \mathrm{~mL}$ de meio nutritivo $+30 \mathrm{~cm}^{3}$ de areia fina $+7 \mathrm{~g} \mathrm{~L}^{-1}$ de ágar. $* *$ médias seguidas de letras minúsculas diferentes na coluna e maiúsculas na linha diferem estatisticamente entre si pelo teste de Scott-Knott a 5\% de probabilidade de erro. A letra "a" refere-se ao melhor resultado. $* * *$ AS (Acurácia Seletiva) $=\sqrt{1-(1 / F c)}$, em que $\mathrm{Fc}=$ valor de $\mathrm{F}$ calculado. AS $=0,9=$ muito alta; AS entre 0,7 e $0,9=$ alta; AS entre 0,5 e $0,7=$ moderada; $\mathrm{e}=0,5=$ baixa

inclusive, observada diferença significativa entre as médias de quaisquer tratamentos. Após 60 dias de cultivo, na testemunha $(\mathrm{M}+\mathrm{A})$ e naqueles dois tratamentos que continham vermiculita como substrato (os quais diferiram estatisticamente dos demais, mas não diferiram entre si), foi observada intensa formação calogênica (Tabela 2, Figura 1E) na base das brotações. As médias observadas nestes três tratamentos, na segunda avaliação, diferiram significativamente daquelas verificadas nos primeiros 30 dias de cultivo in vitro. Nos demais tratamentos, que haviam apresentado -reduzida e não significativa - formação de calos na base das brotações nos primeiros 30 dias, aos 60 dias, não mais foi observada a presença dessas estruturas, uma vez que foram retiradas por ocasião da transferência das brotações para o meio de cultivo fresco e, provavelmente, em decorrência do período de cultivo, estabeleceu-se um novo balanço na relação auxina/ citocinina, não favorecendo a calogênese.

De maneira semelhante ao que foi observado com canafístula no presente estudo, explantes de cultivares de mirtilo (Vaccinium ashei Reade cv. 'Delite' e V. corymbosum L. cv. 'Georgiagem') enraizados em meio nutritivo WPM contendo $7 \mu \mathrm{M} \mathrm{L}^{-1}$ de AIB, na presença de diferentes substratos, também apresentaram intensa formação de calos na base, principalmente, naqueles contendo vermiculita (DAMIANI \& SCHUCH, 2009).
Para a formação in vitro de raízes, foi observada interação entre meio de cultivo e período de avaliação ( $\mathrm{P}=0,0090 ; \mathrm{AS}=0,81)$ (Tabela 2). Após 30 dias, somente foi observada - e em porcentagens reduzidas e que não diferiram significativamente dos demais tratamentos - formação de raízes nos tratamentos contendo como substrato, além do meio nutritivo, vermiculita + ágar, Plantmax ${ }^{\circledR}$ ou areia. Aos 60 dias, formaram-se raízes em todos os tratamentos avaliados. O melhor resultado $(36,78 \%)$ foi obtido no tratamento que continha, como substrato, vermiculita e ágar $(\mathrm{M}+\mathrm{V}+\mathrm{A})$, que diferiu dos demais, os quais, por sua vez, não diferiram entre si (Tabela 2). Além de maior formação de raízes, o meio de cultivo $\mathrm{M}+\mathrm{V}+\mathrm{A}$ também se destacou pela qualidade do sistema radicular formado, uma vez que foi observada a formação de raízes secundárias (Figura 1F), diferentemente do que ocorreu nos demais tratamentos (Figura 1D). Essa superioridade pode ser atribuída ao meio de cultivo mais poroso, obtido com a inclusão de vermiculita, que, combinada com o meio nutritivo e o ágar, proporcionou condições mais favoráveis ao desenvolvimento do sistema radicular. Quanto ao período de avaliação, as maiores porcentagens de formação de raízes observadas após 60 dias de cultivo sugerem que é necessário um período superior a 30 dias para que ocorra a formação in vitro de raízes em canafístula, nas condições testadas. 
No porta-enxerto de pessegueiro (Prunus sp.) cv. 'Mr. S. 1/8', foi possível obter um alto enraizamento no meio MS adicionado de vermiculita, o que permitiu a substituição do ágar por vermiculita no meio de enraizamento (VIAGANÓ et al., 2007). A indução do enraizamento e o desenvolvimento das raízes adventícias foram mais eficientes em ágar, seguido da mistura vermiculita + ágar, em composição com meio nutritivo MS acrescido de $1,0 \mathrm{mg} \mathrm{L}^{-1}$ de AIB $(4,92 \mu \mathrm{M})$, em dois porta-enxertos de macieira. Além disso, quando o desenvolvimento das raízes ocorreu em vermiculita ou em Plantmax ${ }^{\circledR}$, formaramse raízes mais curtas e com maior densidade de pelos radiculares, devido, provavelmente, à maior aeração nesses substratos, em relação ao meio solidificado com ágar (HOFFMANN et al., 2001; JAY-ALLEMAND, 1992). Para um porta-enxerto de macieira (Malus pumilla 'M-9'), no meio contendo vermiculita como substrato, combinada ao meio nutritivo MS (MURASHIGE \& SKOOG, 1962), cuja concentração de sais foi reduzida à metade $(\mathrm{MS} / 2)$ e 1,0 $\mathrm{mg} \mathrm{L}^{-1}$ de ácido indol acético - AIA (a $5,7 \mu \mathrm{M}$ ), a percentagem de miniestacas enraizadas com formação de raízes secundárias foi de $71,6 \%$, valor superior àquele obtido nas miniestacas enraizadas em meio contendo ágar e cinza vegetal (VIEIRA et al., 2007). Em geral, as raízes produzidas na presença de vermiculita apresentam-se mais rústicas, alongadas, com ramificações e presença de pelos absorventes e, no transplante para a aclimatização, essas características são determinantes para a obtenção de uma alta taxa de sobrevivência de plantas (JAY-ALLEMAND et al., 1992; VIEIRA et al., 2007; YU et al., 2000). De maneira semelhante, em pereira (Pyrus communis L.), quando foram utilizados ágar e vermiculita como substrato para o enraizamento, somente na presença de vermiculita, os explantes originaram um sistema radicular ramificado, dotado de pelos absorventes. Tal resultado foi considerado satisfatório, uma vez que a vermiculita, além de ser um substrato barato, reduz o custo da matéria-prima, se comparado ao ágar (LEITE et al., 2002).

A utilização de meio de cultivo contendo Plantmax $^{\circledR}$, nas condições testadas, compromete a sobrevivência de brotações de canafístula na formação de raízes. Ocorre intensa formação de calos na base das brotações, após 60 dias de cultivo in vitro, quando a vermiculita é utilizada no meio de cultivo para indução de raízes. Após 60 dias de cultivo in vitro, é possível obter formação de raízes em todos os meios de cultivo avaliados. No entanto, melhores resultados são obtidos com a utilização de vermiculita, meio nutritivo MS e ágar, tanto quantitativamente como em relação à qualidade do sistema radicular formado. É necessário um período adicional de 30 dias de cultivo, em meio de cultivo fresco, 30 dias após a inoculação das brotações, para promover incremento na formação in vitro de raízes em canafístula.

\section{REFERÊNCIAS}

AYRES, M. et al. BioEstat 3.0: aplicações estatísticas nas áreas das ciências biológicas e médicas. Belém, PA: Sociedade Civil Mamirauá, 2007. 364p. Il.

BASSAN, J.S. et al. Oxidação fenólica, tipo de explante e meios de cultura no estabelecimento in vitro de canafístula (Peltophorum dubium (Spreng.) Taub.). Ciência Florestal, Santa Maria, v.16, n.4, p.381-390, 2006. Disponível em: <http://redalyc.uaemex.mx/ redalyc/pdf/534/53416403.pdf >. Acesso em: 04 jun. 2012.

DAMIANI, C.R.; SCHUCH, M.W. Diferentes substratos e ambientes no enraizamento in vitro de mirtilo. Ciência Rural, Santa Maria, v.39, n.2, p.563-566, 2009. Disponível em: <http:// www.scielo.br/pdf/cr/v39n2/a40v39n2.pdf >. Acesso em: 29 mai. 2012 .

DONADIO, N.M.M.; DAMATTÊ, M.E.S.P. Morfologia de frutos, sementes e plântulas de canafístula (Peltophorum dubium (spreng.) Taub.) e jacarandá-da-bahia (Dalbergia nigra (vell.) Fr.all. Ex benth.) - Fabaceae. Revista Brasileira de Sementes, Brasília, v.22, n.1, p.64-73, 2000. Disponível em: <http://www. abrates.org.br/revista/artigos/2000/v22n1/artigo10.pdf $>$. Acesso em: 29 mai. 2012.

FARIA, R.T. et al. Propagação in vitro de Oncidium baueri Lindl. (Orchidaceae) sem uso de ágar. Acta Scientiarum Agronomy. Maringá, v.28, n.1, p.7174, 2006. Disponível em: $<$ http://eduemojs. uem.br/ojs/index.php/ActaSciAgron/article/view/1672/1040>. Acesso em: 04 mai. 2012. doi: 10.4025

FERREIRA, D.F. Sistemas de análise estatística para dados balanceados. Lavras: UFLA/DEX/SISVAR, 2000. 145p.

FLÔRES, A.V. et al. Estabelecimento in vitro de Peltophorum dubium (Spreng.) Taub. em função das concentrações do meio MS. Cerne, Lavras, v.17, n.4, p.549-553, 2011. Disponível em: $<$ http:// www.dcf.ufla.br/cerne/administracao/publicacoes/m598v17n4o14. pdf $>$. Acesso em: 04 mai. 2012.

HOFFMANN, A. et al. Substratos na indução e desenvolvimento in vitro de raízes em dois porta-enxertos de macieira. Pesquisa Agropecuária Brasileira, Brasília, v.36, n.11, p.1371-1379, 2001. Disponível em: <http://www.scielo.br/pdf/pab/v36n11/6810.pdf>. Acesso em: 29 mai. 2012

JAY-ALLEMAND, C. et al. Root development of in vitro hybrid walnut microcuttings in a vermiculite-containing gelrite medium. Scientia Horticulturae, n.3-4, v.51, p.335-342, 1992. Disponível em: <http://www.sciencedirect.com/science/ article/pii/030442389290132V>. Acesso em: 12 set. 2011. Doi:10.1016/0304-4238(92)90132-V.

LEITE, G.B. et al. Use of vermiculite as a substrate and effect of light on in vitro rooting of pears, cv. Bartlett and clone $\mathrm{OHxF} 97$. Ciência e Agrotecnologia, Lavras, v.26, n.5, p.977-982, 2002. 
MURASHIGE, T.; SKOOG, F. A revised medium for rapid growth and bio-assays with tobacco tissue cultures. Physiologia Plantarum, Copenhagen, v.1, p.437-496, 1962.

VIAGANÓ, R.C. et al. Enraizamento in vitro do porta-enxerto de Prunus cv. Mr. S. 1/8: concentrações de IBA em meio de cultura acrescido de ágar ou vermiculita. Bioscience Journal, Uberlândia, v. 23, n.3, p.60-65, 2007.

RESENDE, M.D.V.; DUARTE, J.B. Precisão e controle de qualidade em experimentos de avaliação de cultivares. Pesquisa Agropecuária Tropical, Goiânia, v.37, n.3, p.182-194, 2007.
VIEIRA, R.L. et al. Efeito de substratos porosos no enraizamento in vitro do porta-enxerto de macieira M-9 (Malus pumilla). Revista Brasileira de Fruticultura, Jaboticabal, v.29, n.1, p.128-132, 2007. Disponível em: <http://www.scielo. br/pdf/\%0D/rbf/v29n1/a28v29n1.pdf>. Acesso em: 29 mai. 2012.

YU, T. et al. Efficient rooting for establishment of papaya plantlets by micropropagation. Plant Cell, Tissue and Organ Culture, v.61, n.1, p.29-35, 2000. Disponível em: <http://link. springer.com/article/10.1023/A\%3A1006475901439>. Acesso em: 29 mai. 2012. Doi: 10.1023/A:1006475901439

Ciência Rural, v.44, n.2, fev, 2014. 